\title{
Juvenile growth of black spruce (Picea mariana [Mill.] BSP) stands established during endemic and epidemic attacks by spruce budworm [Choristoneura fumiferana [Clemens]) in the boreal forest of Quebec, Canada
}

\author{
by Cornelia Krause ${ }^{1,2}$, Hubert Morin ${ }^{1}$ and Pierre-Y. Plourde ${ }^{1}$
}

\begin{abstract}
In the boreal forest of Quebec, $80 \%$ of harvested black spruce (Picea mariana [Mill.] BSP) stands regenerate naturally. In the remaining $20 \%$, forest regeneration is ensured by planting seedlings and these plantations are expected to increase future forest yields. However, predictions of future yields using the information from very young plantations in this ecosystem may have low accuracy. To compare juvenile growth in plantations versus naturally regenerated stands, and also to evaluate the impacts of spruce budworm Choristoneura fumiferana (Clemens) defoliation periods during the juvenile phase, annual height and volume growth were calculated from measurements on nine black spruce stands. The nine sites consisted of two plantations and seven post-fire, naturally regenerated stands. Of the seven naturally regenerated sites, four were epidemic and 3 endemic. The term "epidemic" refers to stands regenerated during known spruce budworm defoliation periods. The term "endemic" refers to stands regenerated during periods without severe defoliation. For height and volume growth, 5 different methods were used and compared. The annual height and volume growth of all black spruce showed a sigmoid trend, characterized by low values in the first years after germination, followed by an exponential acceleration and finally oscillation around a horizontal asymptote. The black spruce stands established during endemic periods were more productive than those established during epidemic periods, but plantations were the most productive.
\end{abstract}

Key words: black spruce, juvenile growth, plantation, post-fire stands, spruce budworm outbreak, volume, yield

\section{RÉSUMÉ}

Dans la forêt boréale du Québec, $80 \%$ des peuplements récoltés dépinette noire (Picea mariana [Mill.] BSP) se régénèrent naturellement. La régénération du $20 \%$ restant est assurée par des plantations qui devraient augmenter le rendement futur des forêts. Le jeune âge (<20 ans) des plantations dans cet écosystème limite cependant la portée des prédictions futures. Afin dévaluer la croissance juvénile et limpact possible de la tordeuse des bourgeons de lépinette (Choristoneura fumiferana (Clemens)) (TBE) durant la phase juvénile de croissance, les accroissements en hauteur et en volume ont été calculés dans neuf peuplements dépinette noire. Cinq méthodes différentes de calcul ont été comparées. Les neuf sites consistaient en deux plantations et sept peuplements régénérés naturellement après feu. De ces 7 peuplements régénérés naturellement, quatre étaient épidémiques et trois endémiques. Le terme " épidémique » fait référence aux peuplements régénérés durant des périodes connues de défoliation par la TBE. Le terme « endémique » fait référence aux peuplements régénérés durant des périodes sans défoliation par la TBE. La croissance annuelle en hauteur et en volume de toutes les épinettes présente une tendance sigmoïde, caractérisée par des valeurs faibles dans les premières années après la germination, suivie ensuite par une accélération exponentielle et enfin une phase de stagnation. Les peuplements dépinette noire qui se sont régénérés en périodes endémiques ont été plus productifs que ceux en périodes épidémiques, mais restaient inférieurs au volume des plantations.

Mots-clés : épinette noire, croissance juvénile, plantation, peuplements après feu, épidémie de tordeuse des bourgeons de lépinette, volume, rendement

\footnotetext{
${ }^{1}$ Département des Sciences fondamentales, Université du Québec à Chicoutimi, 555 boul. de l'Université Chicoutimi, Québec G7H 2B1.

${ }^{2}$ Corresponding author. E-Mail: ckrause@uqac.ca
} 


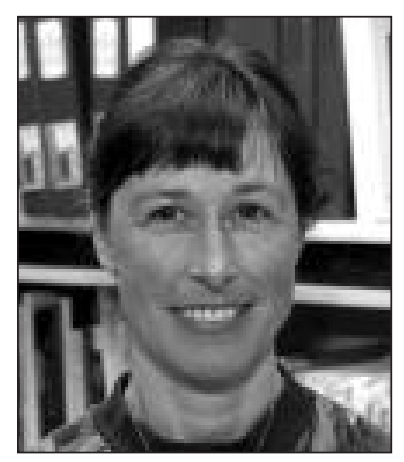

Cornelia Krause

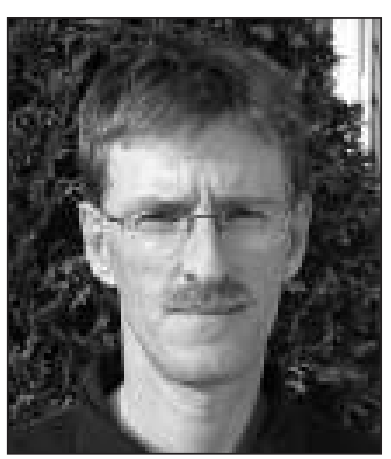

Pierre-Y. Plourde

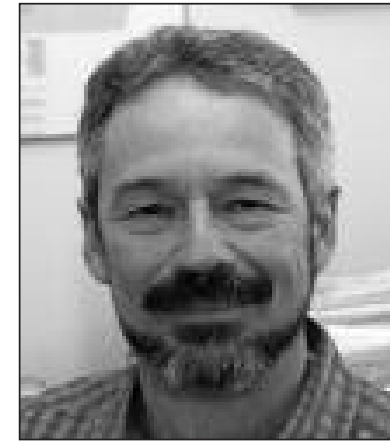

Hubert Morin and shallow soil mantles over bedrock (Viereck and Johnston 1990). Black spruce most commonly grows as pure stands, but when it is associated with other tree species, these will be mainly balsam fir (Abies balsamea (Mill.)), jack pine (Pinus banksiana Lamb.) and white birch (Betula papyrifera Marsh.). Black spruce is classed as shade-tolerant, but is considered less tolerant than balsam fir.

Forest industries favour this species because the wood has high mechanical resistance and fibres are easy to bleach (Singh 1987, Harris 1993, Hatton and Johal 1996, Zhang et al. 1996, Ahmed et al. 2005, Alteyrac et al. 2006). Advance growth, consisting of young seedlings as well as layers around the harvested trees, is protected during the harvesting process. The use of existing overstory trees as a natural shelterwood system is widely applied in eastern Canada, because of the prevalence of over-mature stands that have had an opportunity to accumulate advance regeneration (Groot et al. 2005). This management policy of favouring existing understory regeneration, as practised in Quebec, ensures approximately $80 \%$ of stands are successfully regenerated following harvest. In addition, the protection of advance regeneration allows for the renewal of the genetic pool, while preserving the biodiversity of the dominant shade-tolerant tree species such as black spruce. Planting black spruce is considered whenever natural restocking in the understory following harvest is insufficient and also after fire episodes with insufficient natural regeneration. Around 20\% of harvested black spruce stands in the boreal forest of Quebec need to be planted to ensure sufficient stocking (MRN 2002), accounting for more than 60 million seedlings planted annually in the last few years (Parent and Fortin 2006).

Currently, there are two types of seedlings produced for the boreal forest of Quebec: container grown or bare-root stock. In the last 20 years, seedlings have been produced mostly in small rigid walled containers (Halter et al. 1993, Lindström and Rune 1999, Thiffault et al. 2003). Since the use of seedlings grown in small, rigid-walled containers is relatively recent, they are only found in young plantations. This type of seedling production is expected to increase forest yields in the future because of seed selection and competition control after plantation in the forest (OIFQ 1996).

Measures of site productivity are needed in order to estimate growth and yield of naturally regenerated stands and plantations. For even-aged stands dominated by a single species in North America, site productivity is determined by estimating site index, which is the average height of dominant and co-dominant trees in a forest stand at a reference age (Clutter et al. 1983). To determine the site index, a height-age equation has to be developed based on height and age data obtained from suitable trees. This process usually excludes very young trees (Monserud 1988, Wykoff 1990). For very young trees, growth intercept methods have been developed to estimate site index using measurements of height growth and age to estimate the site index (e.g., Nigh 1999).

As well as measures of site productivity, accurately characterizing juvenile growth is needed as the first step in quantifying the long-term yield for different forest types. Yield estimates in young plantations and in naturally regenerated stands are generally not very accurate (Popovich 1974). While older plantations in the southern regions of Quebec provide better estimates, in the boreal forest of Quebec, the low number of plantations older than 20 years leads to a decrease in the precision of existing yield curves (Prégent et al. 1996). Growth of juvenile trees in young plantations may not reflect long-term growth and yield.

The uncertainty about the impact of natural disturbances on plantation growth is another factor to consider when predicting yields. It is well known that the boreal forest is frequently affected by fire and insect outbreaks (MacLean et al. 1984, Cogbill 1985, Baskerville 1986). In northeastern North America, spruce budworm (Choristoneura fumiferana [Clem.]) periodically defoliated both balsam fir and black spruce (Blais 1965, Hardy et al. 1983, Krause and Morin 1999). Spruce budworm outbreaks caused significant reductions in radial increments in black spruce, even possibly triggering increased tree mortality during severe defoliation periods (Raske and Sutton 1986, Lussier et al. 2002). A reduction of height growth during a defoliation period in young balsam fir was reported by Ghent (1958), Piene and Little (1990) and Piene and MacLean (1999). There is currently little information available about the potential negative impact of spruce budworm outbreaks on black spruce plantations during the seedling stage. To the best of our knowledge, only one study noted that seedling height growth of black spruce seemed to be affected during spruce budworm outbreaks (Fournier 1997).

The objective of this research project was to accurately reconstruct annual and cumulative height and volume growth of black spruce trees in plantations and in naturally regenerated post-fire black spruce stands in the boreal forest of Quebec. The results could then be used to describe the juvenile phase of tree growth and to compare volume growth between study sites. Some of the naturally regenerated stands were initiated during spruce budworm outbreaks (epidemic periods) and others during periods of no defoliation (endemic periods). This allowed the investigation of the 
impact of this defoliator on black spruce development in the juvenile phase. In addition, the study investigated the precision and usefulness of 5 different calculation methods used to predict growth performance.

\section{Materials and Methods}

The trees under investigation were part of two black spruce plantations and seven black spruce natural post-fire stands (Table 1). All study sites were located in the boreal forest of Quebec, between latitudes $49^{\circ}$ and $50^{\circ}$ north and longitudes $70^{\circ}$ and $72^{\circ}$ west in the ecological region of west and east balsam fir-white birch domain and the west spruce-moss domain (Table 1) (MRN 2003). The black spruce plantations were established 1986 and 1990. Post-fire stand germination dates ranged from 1920 to 1983 . All black spruce stands were growing on mesic sites. Ground cover in the older naturally regenerated post-fire stands was mostly characterized by mosses (Pleurozium schreberi (BSG) Mitt. and Sphagnum sp.), lichens (Cladina rangeferina and C. stellaris) and shrubs (Kalmia angustifolia and Ledum groenlandicum). Sparse populations of Chiogenes hispidula, Rubus Idaeus L., Vaccinium angustifolia, V. myrtilloides and other Vaccinium species were also noted. In the planted stands, Salix, Prunus, Alnus and Cornus species were present in small proportions. Common boreal herbaceous species such as Cornus canadensis L., Maianthemum canadense Desp and Coptis groenlandica (Oeder) Fern. were also identified.

The seven natural post-fire stands were labelled as either epidemic or endemic, depending on the conditions under which they regenerated. Epidemic stands regenerated during spruce budworm defoliation periods. Endemic stand regenerated during periods without severe defoliation (Table 1). This classification was based on known historic spruce budworm outbreak periods reported by Morin and Laprise (1990) and by Krause and Morin (1999). The seven post-fire stands were dominated mostly by black spruce accompanied by other species, with the exception of post-fire stand ChiNF71 where jack pine was more abundant (Table 2). Post-fire stands regenerated in epidemic periods are rare; therefore, we took advantage of unpublished data for stand GirF54 (Morin and Fantin unpublished manuscript).

Soil samples showed all the stands were growing on podzols (Table 2). There were slight differences in terms of $\mathrm{pH}$ and nitrate-nitrogen concentrations. However, two post-fire stands, ChiF70 and ChiNF71, showed higher concentrations of calcium-magnesium, potassium and phosphorus.

Stand density on the study sites, based on the count of merchantable plus non-merchantable stems, ranged from

Table 1. Descriptive statistics of the black spruce study site

\begin{tabular}{|c|c|c|c|c|c|c|}
\hline Site & $\begin{array}{l}\text { Stand } \\
\text { origin }\end{array}$ & GPS coordinates & Ecological region & $\begin{array}{l}\text { Year of } \\
\text { origin }\end{array}$ & $\begin{array}{c}\text { Year of } \\
\text { sampling }\end{array}$ & $\begin{array}{l}\text { Outbreak } \\
\text { influence }\end{array}$ \\
\hline BwF20 & fire & $49^{\circ} 21^{\prime} 37^{\prime} \mathrm{N}-71^{\circ} 57^{\prime} 04^{\prime} \mathrm{W}$ & West balsam fir - white birch domain & 1920 & 2005 & endemic \\
\hline SimF22 & fire & $48^{\circ} 12^{\prime} 56^{\prime} \mathrm{N}-71^{\circ} 14^{\prime} 35^{\prime} \mathrm{W}$ & West balsam fir - white birch domain & 1922 & 2005 & endemic \\
\hline GirF54 & fire & $49^{\circ} 16^{\prime} 59^{\prime} \mathrm{N}-72^{\circ} 35^{\prime} 15^{\prime} \mathrm{W}$ & West balsam fir - white birch domain & 1954 & 1999 & epidemic \\
\hline MyrF56 & fire & $47^{\circ} 52^{\prime} 02^{\prime} \mathrm{N}-70^{\circ} 46^{\prime} 34^{\prime} \mathrm{W}$ & East balsam fir - white birch domain & 1956 & 2004 & epidemic \\
\hline ChiF70 & fire & $49^{\circ} 52^{\prime} 56^{\prime} \mathrm{N}-74^{\circ} 19^{\prime} 58^{\prime} \mathrm{W}$ & West spruce - moss domain & 1970 & 2004 & epidemic \\
\hline ChiNF71 & fire & $50^{\circ} 00^{\prime} 23^{\prime} \mathrm{N}-74^{\circ} 12^{\prime} 54^{\prime} \mathrm{W}$ & West spruce - moss domain & 1971 & 2004 & epidemic \\
\hline DesF83 & fire & $49^{\circ} 26^{\prime} 06^{\prime} \mathrm{N}-73^{\circ} 15^{\prime} 19^{\prime} \mathrm{W}$ & West spruce - moss domain & 1983 & 2004 & endemic \\
\hline MvPL86 & plantation & $48^{\circ} 53^{\prime} 01^{\prime} \mathrm{N}-70^{\circ} 33^{\prime} 17^{\prime} \mathrm{W}$ & East balsam fir - white birch domain & 1986 & 2002 & endemic \\
\hline LauPL90 & plantation & $48^{\circ} 14^{\prime} 19^{\prime} \mathrm{N}-71^{\circ} 21^{\prime} 16^{\prime} \mathrm{W}$ & West balsam fir - white birch domain & 1990 & 2005 & endemic \\
\hline
\end{tabular}

Table 2. Dendrometric statistics of the study sites

\begin{tabular}{|c|c|c|c|c|c|c|c|c|c|c|}
\hline \multirow[b]{2}{*}{ Site } & \multirow[b]{2}{*}{ Stems $/$ ha $^{\mathrm{a}}$} & \multirow[b]{2}{*}{$\begin{array}{c}\text { Stand }^{\mathrm{b}} \\
\text { composition }\end{array}$} & \multirow[b]{2}{*}{ Soil type } & \multicolumn{4}{|c|}{$\mathrm{pH}$ values by soil layer } & \multicolumn{3}{|c|}{ Mean values, tree level } \\
\hline & & & & humus & Ae & B & $n$ & $\begin{array}{l}\text { age } \pm \text { std } \\
\text { (years) }\end{array}$ & $\begin{array}{l}\text { dsh } \\
(\mathrm{cm})\end{array}$ & $\begin{array}{l}\text { height } \\
(\mathbf{m})\end{array}$ \\
\hline BwF20 & 3275 & BS & podzol & 3.2 & 4 & 4.6 & 15 & $80 \pm 2$ & $24.6 \pm 4.7$ & $16.8 \pm 1.4$ \\
\hline SimF22 & 3000 & $\mathrm{BS}-\mathrm{BF}$ & podzol & 3.4 & 3.5 & - & 15 & $78 \pm 4$ & $26.2 \pm 6.3$ & $15.8 \pm 2.6$ \\
\hline GirF54 & 2050 & BS - JP & podzol & $\mathrm{n} / \mathrm{a}$ & $\mathrm{n} / \mathrm{a}$ & $\mathrm{n} / \mathrm{a}$ & 10 & $42 \pm 2$ & $14.5 \pm 2.3$ & $8.1 \pm 0.9$ \\
\hline MyrF56 & 1100 & BS - JP & podzol & 3.6 & 3.8 & - & 15 & $36 \pm 5$ & $15.1 \pm 2.5$ & $7.4 \pm 1.2$ \\
\hline ChiF70 & 1000 & $\mathrm{BS}-\mathrm{PB}-\mathrm{TA}$ & podzol & 3.8 & 4 & 4.9 & 14 & $29 \pm 2$ & $9.6 \pm 1.2$ & $4.8 \pm 0.6$ \\
\hline ChiNF71 & 1200 & $\mathrm{JP}-\mathrm{BS}$ & podzol & 5 & 4.7 & 4.5 & 15 & $31 \pm 1$ & $9.3 \pm 0.7$ & $5.3 \pm 1.0$ \\
\hline DesF83 & 4480 & BS & podzol - organic & 3.8 & 4.3 & 4.5 & 15 & $18 \pm 0$ & $6.7 \pm 2.3$ & $2.9 \pm 0.6$ \\
\hline MvPL86 & 3000 & BS & podzol & 4.4 & 4.8 & 5 & 15 & $17 \pm 0$ & $9.4 \pm 2.0$ & $3.9 \pm 1.0$ \\
\hline LauPL90 & 3100 & BS & podzol & 4.3 & 4.2 & 5.3 & 15 & $17 \pm 0$ & $9.5 \pm 1.7$ & $4.9 \pm 0.8$ \\
\hline
\end{tabular}

aAll trees, merchantable and non-merchantable

bBS: black spruce; BF: balsam fir; JP: jack pine; PB: paper birch; TA: trembling aspen (Populus tremuloides Michx.); std: standard deviation; dbh: diameter outside bark at breast height; dsh: diameter outside bark at stump height; n: number of trees analyzed 
1000 to 4480 stems/ha (Table 2). The lowest density was found in the post-fire stands originating in years 1956, 1970 and 1971. The mean diameter at stump height and mean tree height increased with the age of the stand. Standard deviations also increased. The site index was calculated using the method of Nigh (1997), but setting the reference height for age at $1.0 \mathrm{~m}$ (Mailly and Gaudreault 2005). The site index was thus obtained by calculating the top height reached at the time of sampling and the age determined at $1.0 \mathrm{~m}$. Growth intercepts were calculated using the equations presented by Mailly and Gaudreault (2005) for each age ${ }_{100}$ from one to the last year measured in given stands. Site index values in Table 2 refer to the calculation at the age of sampling.

Fifteen trees were randomly selected within each black spruce stand, with the exception of stands GirF54 and ChiF70, where only 10 and 14 trees were sampled, respectively. In order to reconstruct the annual growth of each tree accurately, it was essential to extract the whole stump to locate the root-shoot interface. If the interface was unidentifiable, the stump had to be rejected and a new tree had to be sampled to replace it. One black spruce in stand ChiF70 was rejected because the root-shoot interface was missing, but it was not replaced. Access concerns did not allow us to return to stand GirF54 for additional sampling.

Each tree was cut at soil level and the stump was excavated. For each sampled tree, the root-shoot interface was located on the stump by identifying the anatomical changes between the pith and the central cylinder. Layered regeneration was excluded from this analysis. Second, locations of all bud scars along the stem were recorded, from the top of the tree downwards to the root-shoot interface. The location of the bud scars was used in one approach to reconstruct the height development over time. In the lower parts of the stem, especially close to the stump, the count of annual tree-rings in transverse sections was essential to offset the difficulty of locating the oldest bud scars. The oldest stands (BwF20, SimF22, GirF54) were excluded from this analysis due to the difficulty of locating bud scars formed during the first years after germination. The average annual height growth was calculated from the cambial age of each tree for each stand studied. The average annual height growth is thus given from beginning of germination (without looking to calendar years). Values were averaged for each site.

Radial growth was measured at $50-\mathrm{cm}$ intervals along the stem, starting from the root-shoot interface up to the top of the tree. Transverse sections were cut, dried and the surface gradually sanded ( 80 to 400 grit). Ring widths were measured along two radii with an accuracy of $0.01 \mathrm{~mm}$ using a manual Henson or a semiautomatic Win-Dendro tree-ring measuring device (Guay et al. 1992). The two radii were then averaged to obtain a ring width for each ring and each section (stem analysis data). The tree-ring measurements were crossdated on a light table and afterwards verified with the COFECHA program (Holmes 1983) and dates were corrected if necessary to minimise the introduction of errors in the volume calculations by year.

\section{Annual height and volume growth and yield}

In order to calculate annual growth and yield of height and volume, first the trees were reconstructed at each age for the entire measurement period. As noted, the cambial age of each tree was used to compare the juvenile growth of trees at the same stage of development. Two methods were used to reconstruct the trees: the Carmean (1972) method and the bud scar method. For both methods, the radius for each year and the top and bottom of each section were obtained by summing the ring widths up to that year. Then, for the Carmean method, the height was estimated at each age, using the annual ring width measurements taken every $50 \mathrm{~cm}$ over the tree stem along with stem lengths. In this way, the radii and the lengths were reconstructed for each tree at each age, with the top section of the reconstructed trees having lengths of $\leq 50 \mathrm{~cm}$ (Fig. 1). For the bud scar method, a similar approach was used, except that the ring width measurements along the stem were combined with the exact position of the bud scars in estimating height. The Carmean method was selected because it is the most precise among the widely used methods to estimate annual heights from stem analysis data. The bud scar method is much more laborious, but is more precise, especially in the first years of tree establishment when height growth rate is slow. The formula used in both these calculations is:

$$
V=\frac{1}{3} \pi h\left(a^{2}+a b+b^{2}\right)
$$

where $\quad \mathrm{V}$ : volume of a $50 \mathrm{~cm}$ segment;

h: length of a segment;

a: radius at the top of a segment; and

b: radius at the bottom of a segment.

This formula is exact for a truncated cone shape. For the top segment, the length was less then or equal to $50 \mathrm{~cm}$, as calculated from the estimated height, and the top radius was 0 , resulting in the equation for a cone shape. The segments were then added to obtain the volume yield of the tree. This was repeated for each of the reconstruction methods, resulting in two estimates of volume yield at each age. Differences in volume yield for adjacent years resulted in annual volume growth.

In the last 3 methods, only final volume yield was calculated, and there was no annual reconstruction of trees. For the third and the fourth method, the diameter inside bark at 30\% of the total stem height $\left(\mathrm{D}_{0.3}\right)$ and the stem height were used to calculate cumulative volume directly using the equation (Forslund 1982):

$$
V=\frac{A}{(A+2)}(1-Y)^{\prime 2 / N} \frac{\pi D_{y}{ }^{2} H C}{4}
$$

where $\quad \mathrm{V}$ : total stem volume (outside bark);

$\mathrm{D}_{\mathrm{Y}}$ : inside bark diameter at a relative height $\mathrm{Y}=\mathrm{h} / \mathrm{H}$

$\mathrm{h}$ : height to the measurement position from the ground;

$\mathrm{H}$ : total stem height;

A: the power coefficient that determines the shape of the stem profile; and

$\mathrm{C}$ : the unit conversion factor

The parameter A was initially set to 1 for an assumed cone shape. For the fourth volume yields, A was set to 2 for a paraboloid shape. 


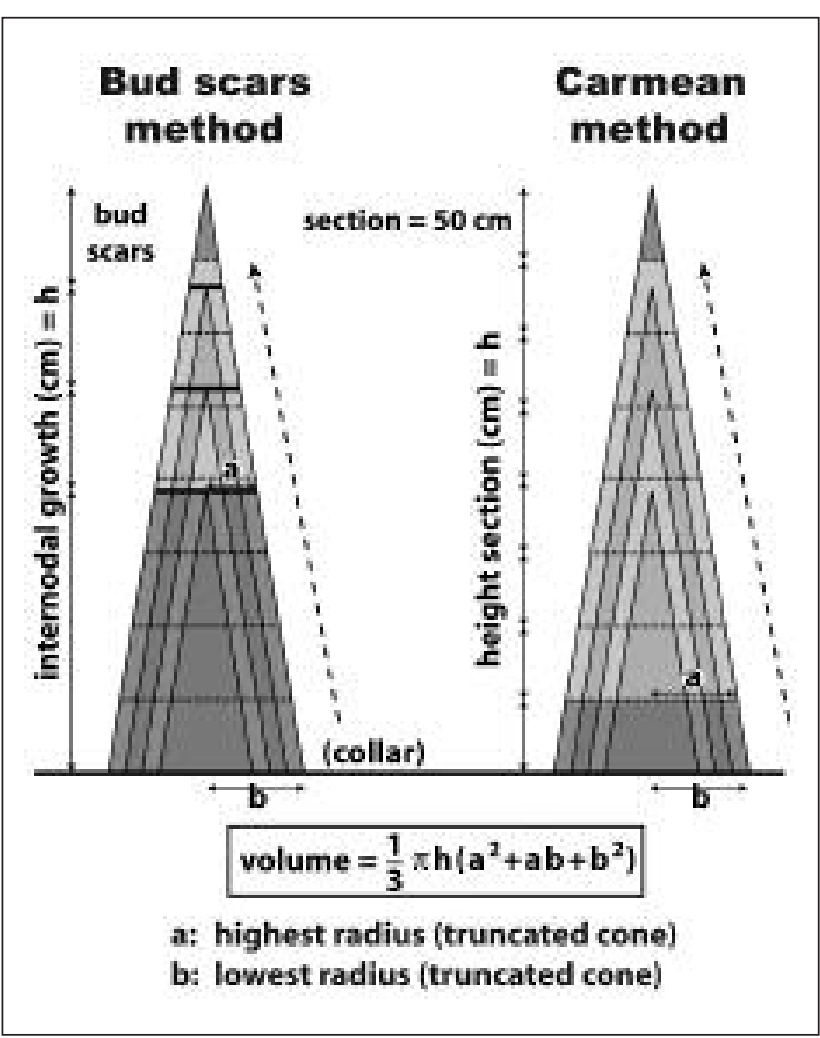

Fig. 1. Bud scar versus Carmean methods for reconstruction of tree heights and radial growth over time.

Finally, for the fifth method, the volume was calculated using the formula for a cone using the basal radius and the total stem height:

$$
\text { [3] } \quad V=\frac{1}{3}\left(\pi r^{2} h\right)
$$

where V: volume

r: radius at stem base;

h: total stem height.

The cone method was chosen to calculate the total volume of each tree analysed because of the widespread use of this assumed shape in several studies.

\section{Statistical Analyses}

To reduce the complexity in the analysis, growth and yield of height and volume measurements were averaged for all trees by stand, resulting in nine observations for each age. Differences in cumulative shoot lengths and cumulative volumes between stand types were compared using a repeated measures analysis of variance (ANOVA) in a split-plot design to trends over time and differences in stand types. Statistical analyses were done using the SAS JMP software package with the GLM procedure and the EMS option (SAS Institute Inc. 2003). Main plots consisted of stand types: plantation, endemic and epidemic. The repeated-measures factor, time, had 13 levels (years 1 to 13) for height and for volume yields. In order to produce a balanced analysis, we kept only the first 13 years, even though some plots were measured for longer time periods. Within-plot analysis of contrasts was conducted to examine trends over these periods. Two orthogonal polynomial contrasts with time were tested (linear, quadratic) (Gumpertz and Brownie 1993). P values obtained from analysis are presented with Greenhouse-Geisser-adjusted $\left(\mathrm{P}_{\mathrm{G}-\mathrm{G}}\right)$ probabilities to correct the violations of the assumption of sphericity (Milliken and Johnson 1992, Quinn and Keough 2002). This estimate, as expressed by the epsilon statistic, is used to adjust the df for within plots/subjects tests downwards to make the tests more conservative, since non-sphericity increases the risk of Type I error (Quinn and Keough 2002). When $\epsilon$ is less than 0.75 , the correction based on the Greenhouse-Geisser is better (Keselman and Keselman 1993).

\section{Results}

\section{Annual height growth and yield}

The annual height yield was reconstructed for all study sites using both the Carmean and bud scar methods, except that for the 3 oldest post-fire stands (BwF20, SimF22, GirF54), only the Carmean method was used due to the difficulty of retracing the bud scars. The annual height growth was variable on a year-to-year basis (Fig. 2A). Within all black spruce stands, the mean annual height growth increased with cambial age. The mean annual height growth was much faster in the plantations, which had heights of $30 \mathrm{~cm}$ already at age 9 (Fig. 2A). In the endemic post-fire stands, the mean annual heights were below $20 \mathrm{~cm}$ for the first 14 years, whereas in the epidemic post-fire stands, these values were below $10 \mathrm{~cm}$ for the first 15 years.

Height yields over time for all nine black spruce stands followed an exponential curve (Fig. 2B). Both plantations showed greater cumulative height growth than the post-fire stands. Endemic stands registered higher cumulative height values than epidemic stands. The repeated measures ANOVA indicated that there is a strong interaction between time and the main factor Stand type (St), suggesting that the annual height yield trends differ among stands ( $<$ 0.0001) (Table 3; Fig. 2B).

There were significant linear effects in the component of the regression for interactions $\mathrm{T} \times \mathrm{PL}$ vs $\mathrm{T} \times \mathrm{END}(\mathrm{p}=$ $0.0011), T \times P L$ vs $T \times E P I(p<0.0001)$ and for $T \times E N D$ vs $\mathrm{T} \times \mathrm{EPI}(\mathrm{p}=0.0016)$ (Table 3$)$. There is a strong effect in the curvature of the regression, as indicated by the quadratic interactions, $\mathrm{T} \times \mathrm{PL}$ vs $\mathrm{T} \times \mathrm{END}(\mathrm{p}=0.0037)$ and $\mathrm{T} \times \mathrm{PL}$ vs $\mathrm{T} \times \mathrm{EPI}(\mathrm{p}=0.0009)$. The quadratic contrasts with time indicate no significant interactions for $\mathrm{T} \times \mathrm{END}$ vs $\mathrm{T} \times \mathrm{EPI}$ $(\mathrm{p}=0.1877)$. The significant interactions indicate that the lines are not parallel.

\section{Annual volume growth and yield}

The two estimates of annual volume yields were compared. The bud scar method using a cone frustum for each segment (Method 1) was used as the standard for comparison, as it was considered most accurate. Annual volume yields using the bud scar versus the Carmean method to obtain heights (Methods 1 and 2) were similar. Comparing all 5 volume yield estimates for the final measurement, the Carmean method had a mean overestimation of cumulative volume for the final time period of only $2 \%$ in the plantations and endemic stands (Table 4), and 3\% in epidemic sites, relative to the bud scar method. The 3 other methods used to calculate cumulative volume require more simple calculations and fewer measure- 

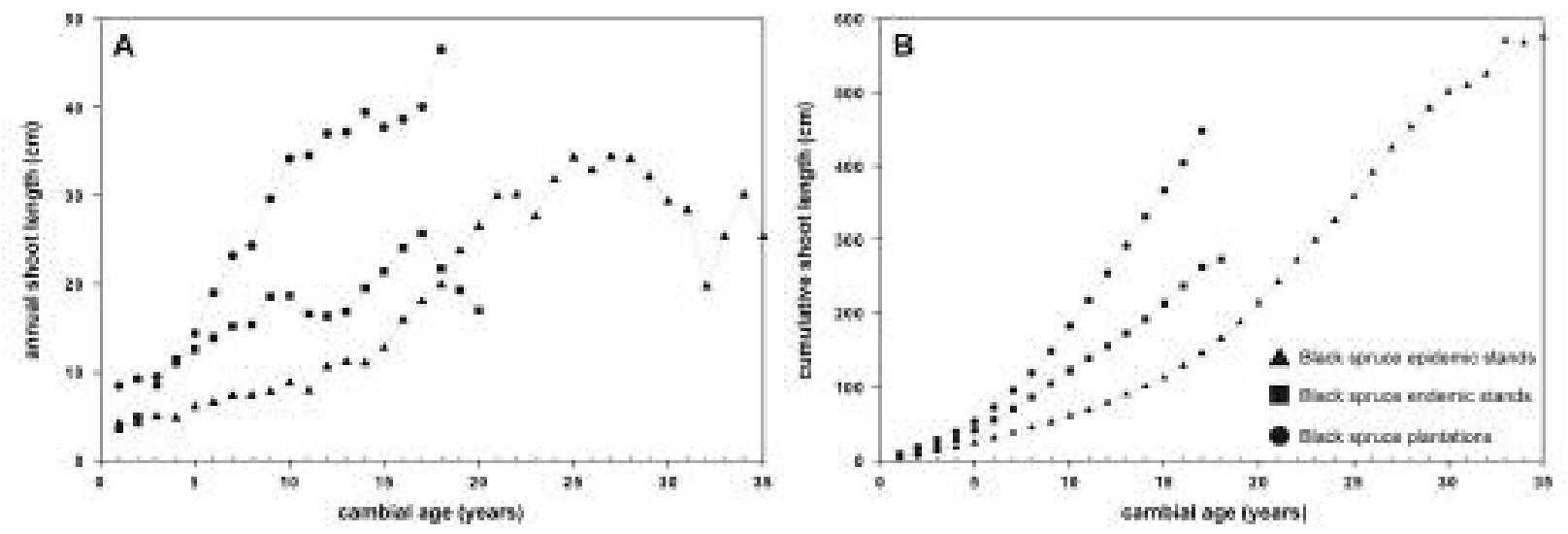

Fig. 2. Mean annual height growth $(\boldsymbol{A})$ and yield $(\mathbf{B})$ curves by stand for 15 trees per site. Solid lines refer to epidemic and endemic stands respectively. Dotted black lines refer to black spruce plantations.

Table 3. Results of repeated measures ANOVA of differences annual height and volume yields between plantation (P), endemic (END) and epidemic (EPI) stand types.

A) Between- and within-subjects analysis

Annual height yield

Annual volume yield

\begin{tabular}{|c|c|c|c|c|c|c|c|c|}
\hline Source & DfNum $^{a}$ & DfDen & F ratio & $\mathbf{P}$ & DfNum $^{a}$ & DfDen & F ratio & $\mathbf{P}$ \\
\hline \multirow{3}{*}{ Stand type (St) } & Between subjects & - & - & - & Between subjects & - & - & - \\
\hline & 2 & 3 & 6859.3 & $<0.0001$ & 2 & 6 & 161.8 & $<0.0001$ \\
\hline & Within subjects & - & - & $P_{\mathrm{G}-\mathrm{G}}{ }^{\mathrm{b}}$ & Within subjects & - & - & $P_{G-G}{ }^{b}$ \\
\hline Time $(\mathrm{T})$ & 1.3 & 3.9 & 1623.0 & $<0.0001$ & 1.3 & 7.6 & 360.8 & $<0.0001$ \\
\hline Stand type $(\mathrm{St}) \times \mathrm{T}$ & 2.6 & 3.9 & 244.2 & $<0.0001$ & 2.5 & 7.6 & 193.8 & $<0.0001$ \\
\hline
\end{tabular}

B) Within-subjects analysis : P-values for orthogonal polynomial contrasts on time

\begin{tabular}{|c|c|c|c|c|c|c|c|c|}
\hline Source & DfNum & $\mathbf{P}$ & & & DfNum & $\mathbf{P}$ & & \\
\hline $\mathrm{T}$ & - & - & & & - & - & & \\
\hline Linear & 2 & 0.0002 & & & 2 & $<0.0001$ & & \\
\hline Quadratic & 2 & $\begin{array}{c}0.0021 \\
P_{G-G}^{b}\end{array}$ & & & 2 & $\begin{array}{c}<0.0001 \\
P_{G-G}^{b}\end{array}$ & & \\
\hline$S_{0}$ & & $\begin{array}{l}\mathrm{T} \times \mathrm{PL} \text { vs } \\
\mathrm{T} \times \mathrm{END}\end{array}$ & $\begin{array}{c}\mathrm{T} \times \mathrm{PL} \text { vs } \\
\mathrm{T} \times \mathrm{EPI}\end{array}$ & $\begin{array}{c}\mathrm{T} \times \mathrm{END} \text { vs } \\
\mathrm{T} \times \mathrm{EPI}\end{array}$ & & $\begin{array}{l}\mathrm{T} \times \mathrm{PL} \text { vs } \\
\mathrm{T} \times \mathrm{END}\end{array}$ & $\begin{array}{c}\mathrm{T} \times \mathrm{PL} \text { vs } \\
\mathrm{T} \times \mathrm{EPI}\end{array}$ & $\begin{array}{c}\mathrm{T} \times \mathrm{END} \text { vs } \\
\mathrm{T} \times \mathrm{EPI}\end{array}$ \\
\hline St $\times$ Linear & 1 & 0.0011 & $<0.0001$ & 0.0016 & 1 & $<0.0001$ & $<0.0001$ & 0.0594 \\
\hline St $\times$ Quadratic & 1 & 0.0037 & 0.0009 & 0.1877 & 1 & $<0.0001$ & $<0.0001$ & 0.0658 \\
\hline
\end{tabular}

aDfNum: degree of freedom at numerator; DfDen: degree of freedom at denominator;

${ }^{b} \mathrm{P}_{\mathrm{G}-\mathrm{G}}$ values from univariate analysis are presented with Greenhouse-Geisser-adjusted probabilities; Bold-faced $P$ values are significant at $\alpha=0.05$ level.

ments. The cone 1/3 method using Forslund's taper (Method 3; $\mathrm{A}=1$ ) underestimated the cumulative tree volume by a mean of $10.5 \%$ and the paraboloid method using Forslund's (1982) taper model (Method 4; $\mathrm{A}=2$ ) underestimated it by $6 \%$ on average. The cone method (Method 5) was even less precise. On average, it overestimated the cumulative volume of the trees by $37 \%$. The maximum overestimation for one study site was as high as $78 \%$ relative to Method 1 .

Using the reconstructed trees from the bud scar or the Carmean (1972) method, the annual volume growth and yield over time were examined for the entire measurement period. All post-fire stands produced little annual volume during the first years after germination (Fig. 3A). This first phase of development was followed by accelerated growth, which started earlier in planted sites than in the post-fire sites. This second developmental phase of annual volume can be modeled by an exponential function and lasted between 35 and 40 years. In the plantations, the annual volume increased more rapidly.

All planted and post-fire sites had an exponential curve pattern for volume yields over time (Fig. 3B). The mean annual 
Table 4. Mean cumulative volume $\left(\mathrm{m}^{3} \times 10^{-4}\right)$ of 15 trees by stand according to 5 different methods without bark. Differences between the calculation methods are expressed in percentage.

\begin{tabular}{|c|c|c|c|c|c|c|c|c|c|c|c|}
\hline \multirow[b]{2}{*}{ Site } & \multirow[b]{2}{*}{ species } & \multirow[b]{2}{*}{ age } & \multirow{2}{*}{$\begin{array}{c}1 \\
\text { bud scars }\end{array}$} & \multirow{2}{*}{$\begin{array}{c}2 \\
\text { carmean }\end{array}$} & \multirow{2}{*}{$\begin{array}{c}3 \\
\text { cone1/3 }\end{array}$} & \multirow{2}{*}{$\begin{array}{c}4 \\
\begin{array}{c}\text { para- } \\
\text { boloid }\end{array}\end{array}$} & \multirow{2}{*}{$\begin{array}{c}5 \\
\text { cone }\end{array}$} & \multicolumn{4}{|c|}{ differences \% } \\
\hline & & & & & & & & 1 vs 2 & 1 vs 3 & 1 vs 4 & 1 vs 5 \\
\hline BwF20 & BS & 80 & - & 1670.04 & & & - & - & - & - & - \\
\hline SimF22 & BS & 78 & - & 2146.67 & & & - & - & - & - & - \\
\hline GirF54 & BS & 43 & - & 347.56 & & & - & - & - & - & - \\
\hline MyrF56 & BS & 36 & 267.32 & 278.45 & 246.58 & 258.90 & 425.16 & $2 \%$ & $-13 \%$ & $-8 \%$ & $68 \%$ \\
\hline ChiNF71 & BS & 31 & 94.17 & 96.61 & 85.17 & 89.43 & 103.17 & $3 \%$ & $-11 \%$ & $-6 \%$ & $13 \%$ \\
\hline ChiF70 & BS & 29 & 79.00 & 80.89 & 69.84 & 73.33 & 124.75 & $2 \%$ & $-11 \%$ & $-6 \%$ & $53 \%$ \\
\hline DesF83 & BS & 18 & 17.59 & 17.98 & 14.92 & 15.66 & 28.17 & $3 \%$ & $-16 \%$ & $-12 \%$ & $52 \%$ \\
\hline LauPL90 & BS & 17 & 80.20 & 80.95 & 78.34 & 82.25 & 129.76 & $1 \%$ & $-7 \%$ & $-3 \%$ & $78 \%$ \\
\hline MvPL86 & BS & 17 & 64.86 & 65.58 & 58.06 & 60.96 & 74.65 & $2 \%$ & $-8 \%$ & $-3 \%$ & $10 \%$ \\
\hline
\end{tabular}

BS: black spruce;

age: age of the oldest tree analysed

1: volume growth method including tree-ring width and shoot length

2: volume growth method including tree-ring width

3: volume growth method using the power function of a cone

4: volume growth method using the power function of a paraboloid

5: volume growth method including tree height and diameter at stump height only

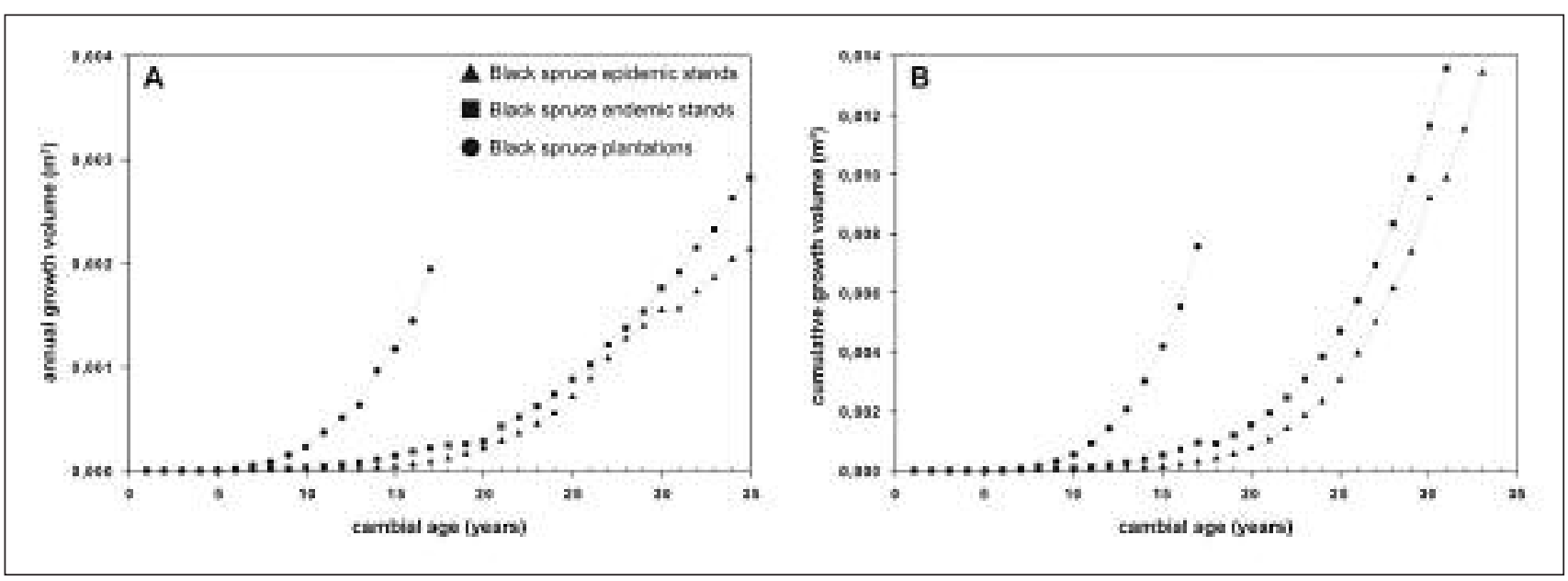

Fig. 3. Mean annual volume growth $(\boldsymbol{A})$ and yield $(\mathbf{B})$ curves by stand for 15 trees per site. Solid lines refer to epidemic and endemic stands. Dotted black lines refer to black spruce plantations.

volume yield of the post-fire black spruce was low for the first 10 to 25 years, followed by an accelerating trend. However, the planted black spruce increased the volume yields earlier.

The repeated measures ANOVA tests suggested that there is a strong interaction between time and the main factor Stand type (St), meaning that the annual volume yield curves differ across stands $(\mathrm{p}<0.0001)$ (Table 3, Fig. 3B). There were significant linear effects in the component of the regression for interactions $\mathrm{T} \times \mathrm{PL}$ vs $\mathrm{T} \times \mathrm{END}(\mathrm{p}<0.0001)$ and $\mathrm{T}$ $\times$ PL vs $\mathrm{T} \times \mathrm{EPI}(\mathrm{p}<0.0001)$. The linear contrasts with time indicate no significant interaction for $\mathrm{T} \times \mathrm{END}$ vs $\mathrm{T} \times \mathrm{EPI}$ $(p=0.0594)$. There is a strong effect in the curvature of the regression for interactions $\mathrm{T} \times \mathrm{PL}$ vs $\mathrm{T} \times \mathrm{END}(\mathrm{p}<0.0001)$ and $\mathrm{T} \times \mathrm{PL}$ vs $\mathrm{T} \times \mathrm{EPI}(\mathrm{p}<0.0001)$. Quadratic contrasts with time indicate no significant effect in interaction $\mathrm{T} \times \mathrm{END}$ vs $\mathrm{T} \times \operatorname{EPI}(\mathrm{p}=0.0658)$. The significant interactions indicate that the lines are not parallel.

\section{Discussion}

Characterization of juvenile annual and cumulative volume In order to reconstruct the juvenile growth of trees, the identification of the root-shoot interface was essential to identify the year of germination (Telewski 1993, Desrochers and Gagnon 1997, Parent et al. 2000, Niklasson 2002, Krause and Morin 2005). This technique is becoming popular among dendroecologists for determining post-fire seedling recruitment (Fritts and Swetnam 1989, Motta 1998, Hellberg et al. 2003, Rozas 2003, Ruffner and Abrams 2003, Payette and Delwaide 2004, Rubino and McCarthy 2004) and for reconstructing stem development in time by using bud scars in measuring the annual height growth (Fantin and Morin 2002, Parent et al. 2002). This time-consuming step was essential in the present study to compare the juvenile growth in different stands from the time of germination and also to compare different methods of volume calculation. Annual volume growth was calcu- 
lated using the reconstructed annual heights and radial growth at different stem heights, using the bud scar method as the standard for comparison to the Carmean method. Our findings clearly demonstrate that the bud scar method takes too much effort for the precision gained when compared to the Carmean (1972) method for determining heights over time, which produces comparable results with less effort.

The juvenile annual height growth pattern of black spruce can be characterized by a gradual increase of height growth before entering a more or less stagnant phase. The annual volume growth in all black spruce stands increased slowly in the first years after germination. This was followed by a period of exponential acceleration and later by a period of gradual decline. This finding is corroborated by many articles and texts on growth of organisms, including Philip (1994), who stated that the growth pattern of most living organisms follows a sigmoid pattern characterized by slow initial and terminal growth rates, with fast growth during the middle life stages, reaching a maximal final size. Generally, the early immature stage finishes when canopy closure occurs (Philip 1994). Many authors subdivide the volume yield curve into youth, maturity and senescence phases, with an exponential acceleration in the maturity phase. Volume growth is known to decline during the senescence phase, but this final phase was not found in the present study, not even in the oldest, over-70-year-old stands. Our results clearly demonstrate time trend changes depending upon the stand type. An accelerated volume yield was visible earlier in the plantations over a time span of 13 years compared to both naturally regenerated stand types. The lower stocking density in plantations offers better light availability for each tree, which increases the growth rate in black spruce (Viereck and Johnston 1990). Furthermore, the regular spacing between planted trees also favours optimal growing conditions (OIFQ 1996). Weeding is another factor that can contribute to the growth potential in plantations (OIFQ 1996).

\section{The impact of spruce budworm defoliation during the germina- tion period of black spruce}

During the 20th century, 3 major spruce budworm outbreaks occurred and caused black spruce growth reductions and tree mortality (Blais et al. 1985, Morin and Laprise 1990, Lussier et al. 2002). Some of the post-fire study stands germinated during these known outbreaks. The height growth in these stands was especially slower compared to the endemic sites. The impact was also visible as a slower volume gain. The impact of spruce budworm on height growth in young suppressed black spruce has been already reported by Fournier (1997). The lower volume values of the epidemic post-fire stands suggest that seedlings planted during an outbreak period may give lower yields than expected from endemic plantations because of the impact of defoliation on height growth. A larger analysis of several black spruce stands with germination during spruce budworm outbreaks is needed to confirm this hypothesis. However, epidemic stands are difficult to find, due in part to the feeding effect of spruce budworms on cones, resulting in an insufficient number of seeds (Simard and Payette 2005).

\section{Characteristics of juvenile annual and cumulative volume and their implication for forest management}

In order to manage forests in a sustainable manner, it is essential to quantify the yield of each stand precisely. Yield tables are well established for natural and planted stands in the southern part of Quebec. In order for these tables to be reliable, trees have to be at least 25 years old. However, the young age of the plantations in the boreal forest makes the use of these tables of limited value. Instead, the stem height of dominant trees in a given year is the most common measurement used (Prégent and Végiard 2000). According to these authors, this parameter is suitable for predicting the long-term yield in the boreal forest. Considering the lack of other yield predictors, the stem height is still widely used. However, the annual height growth of black spruce is very slow during the first 10 years; therefore, the stem height is not an accurate predictor of the production potential of black spruce plantations. Mailly and Gaudreault (2005) introduced a new approach to evaluate the yield in planted stands using internodal growth measurements. This non-destructive method uses measurements of annual height growth and produces results comparable to the bud scar method. The drawback to the Mailly-Gaudreault method is the exclusion of juvenile growth and, consequently, the youngest trees planted. The method needs trees with a minimum height of 1.3 meters.

In the province of Quebec, a total of 332 permanent plots were established in black spruce, aged between 8 and 13 years (Prégent and Poliquin 2006). More than 100 are located in the boreal forest and allow researchers to follow the development and yield of these plantations. Based on tree height and diameter at stem base, Prégent and Poliquin predicted a low yield for the boreal black spruce plantations. The introduction of the diameter at $1 / 3$ of total stem height, combined with the use of a paraboloid power function, would be an appropriate nondestructive tool to evaluate the total volume of black spruce in the juvenile phase of growth as reported by Forslund and Paterson (1994). Our findings, based on both plantations and the seven post-fire stands, showed that the juvenile phase can be used in volume predictions. Trees showed a slow cumulative volume increase in the juvenile phase with a faster volume gain in the planted sites. At age 10, the plantations had a cumulative volume comparable to 14 - to 18 -year-old post-fire stands. Furthermore, this better performance seemed to increase with the age of the trees. Detailed analysis of a larger number of black spruce plantations in the boreal forest, such as those presented in this paper, combined with information about the initial stand density, which influences the amount of light available for each tree, might be necessary to predict the yield of this silvicultural practice in the future. Furthermore, complementary information should be added to reveal the different growing patterns between pure black spruce sites, as often found in plantations and mixed stands as in post-fire sites.

\section{Conclusions}

The juvenile cumulative increment of naturally regenerated and planted black spruces was characterized by a slow increase during the first year of tree establishment. This period was followed by an exponential acceleration, which started earlier in the plantations than in the post-fire sites. A reduced height and volume growth was observed in black spruce from post-fire sites regenerated during spruce budworm outbreaks. More studies are needed to evaluate the impact of spruce budworm defoliation on yield when black spruce is planted during these periods.

The annual height growth of black spruce also showed acceleration and did not follow a linear trend. Consequently, 
applying a linear trend by using tree height at a given age is a very poor yield predictor for black spruce plantations. Methods, such as the one proposed by Mailly and Gaudreault (2005) might be more promising in predicting the long-term yield of boreal plantations on an annual basis. The paraboloid power function (Forslund and Paterson 1994) seems to be a good method for evaluating the total volume at a given age with few measurements. The bud scar method, though very precise, is not recommended for this task, because it is not practical due to its destructive and highly time-consuming nature. The Carmean method, while also destructive, should be favoured over other methods mentioned in this article whenever annual and cumulative volume growth of individual trees is a concern.

\section{Acknowledgements}

Special thanks to both reviewers and the editor for the constructive advices. For his statistical advice, we would like to thank M. Denis Walsh. We would also like to thank Mireille Boulianne, Émilie Lapointe, Sandy Laplante, Maxime Thibeault-Martel, Andres Castro and Patrick Emond, who helped during the field work.

\section{References}

Ahmed, K., N. Isabel., S. Zhang, J. Beaulieu and J. Bousquet. 2005. Transition from juvenile to mature wood in black spruce (Picea mariana). Wood Fib. Sci. 37: 445-455.

Alteyrac, J., A. Cloutier, C. Ung and S.Y. Zhang. 2006. Mechanical properties in relation to selected wood characteristics of black spruce. Wood Fib. Sci. 38: 229-237.

Baskerville, G. 1986. Understanding forest management. For. Chron. 62: 339-347.

Baskerville, G.L. and D.A. MacLean. 1979. Budworm-caused mortality and 20-years recovery in immature balsam fir stands. Canadian Forestry Service, Fredericton (NB). 23 p.

Blais, J.R. 1965. Spruce budworm outbreaks in the past three centuries in the Laurentide Park, Quebec. For. Sci. 11: 130-138.

Blais, J.R.S., R.W. Stark, E.J. Mullins and J. Murphy. 1985. The ecology of the eastern spruce budworm: A review and discussion. In Recent advances in spruce budworm research. Proceedings of the CANUSA Spruce budworm Research Symposium, Bangor, Maine, 16-20 September 1984. pp. 49-59. Canadian Forest Service, Ottawa. Carmean, W.H. 1972. Site Index Curves for Upland Oaks in the Central States. For. Sci. 18: 109-120.

Clutter, J.L., J.C. Fortson, L.V. Pienaar, G.H. Brister and R.L. Bailey. 1983. Timber management: a quantitative approach. John Wiley \& Sons Inc. 334 p.

Cogbill, C.V. 1985. Dynamics of the boreal forests of the Laurentian Highlands, Canada. Can. J. For. Res. 15: 252-261.

Desrochers, A. and R. Gagnon. 1997. Is ring count at ground level a good estimation of black spruce age? Can. J. For. Res. 27: 1263-1267. Fantin, N. and H. Morin. 2002. Croissance juvénile comparée de deux générations successives de semis dépinette noire issus de graines après feu en forêt boréale, Québec. Can. J. For. Res. 32: 1478-1490.

Farrar, J.L. 1995. Trees in Canada. Fitzhenry \& Whiteside Limited. $502 \mathrm{p}$.

Forslund, R.R. 1982. A geometrical tree volume model based on the location of the centre of gravity of the bole. Can. J. For. Res. 12: 215-221.

Forslund, R.R. and J.M. Paterson. 1994. Nondestructive volume estimates of 11-year old jack pine and black spruce using the power function volume model. For. Chron. 70: 762-767.

Fournier, M. 1997. Structure et croissance d'un peuplement d'épinette noire (Picea mariana) issu d'une coupe d'une vingtaine d'années dans la région du Saguenay-Lac-Saint-Jean. Mémoire de maîtrise, Université du Québec à Chicoutimi, Chicoutimi. 106 p.
Fritts, H.C. and T.W. Swetnam. 1989. Dendroecology: a tool for evaluating variations in past and present forest environments. Adv. Ecol. Res. pp. 111-118.

Ghent, A.W. 1958. Studies of regeneration in forest stands devastated by the Spruce budworm. II. Age, height-growth and related studies of Balsam fir seedlings. For. Sci. 4: 135-146.

Groot, A., J.M. Lussier, A.K. Mitchell and D.A. MacIsaac. 2005. A silvicultural systems perspective on changing Canadian forestry practices. For. Chron. 81: 50-55.

Guay, R., R. Gagnon and H. Morin. 1992. A new automatic and interactive tree ring measurement system based on a line scan camera. For. Chron. 68: 138-141.

Gumpertz, M.L. and C. Brownie. 1993. Repeated measures in randomized block and split-plot experiments. Can. J. For. Res. 23: 625-639. Halter, M.R., C.P. Chanway and G.J. Harper. 1993. Growth reduction and root deformation of containerized lodgepole pine saplings 11 years after planting. For. Ecol. Manag. 56: 131-146.

Hardy, Y.J., A. Lafond and L. Hamel. 1983. The epidemiology of the current spruce budworm outbreak in Quebec. For. Sci. 29: 715-725. Harris, G. 1993. Comparison of northern softwood and southern pine fiber characteristics for groundwood publication papers. Tappi J. 76: 55-61.

Hatton, J.V. and S.S. Johal. 1996. Mechanical pulping of commercial thinnings of six softwoods from New Brunswick. Pulp Pap. Can. 97: 93-97.

Hellberg, E., G. Hornberg, L. Ostlund and O. Zackrisson. 2003. Vegetation dynamics and disturbance history in three deciduous forests in boreal Sweden. J. Veg. Sci. 14: 267-276.

Holmes, R.L. 1983. Computer-assisted quality control in tree-ring dating and measurement. Laboratory of tree-ring research, University of Arizona, Tree-Ring Bulletin. pp. 69-78.

Keselman, H.J. and J.C. Keselman. 1993. Analysis of repeated measurements. In L.K. Edwards (ed.). Applied Analysis of Variance in Behavioral Science. pp 105-145. Marcel Dekker, New-York.

Krause, C. and H. Morin. 1999. Tree-ring patterns in stems and root systems of black spruce (Picea mariana) caused by spruce budworms. Can. J. For. Res. 29: 1583-1591.

Krause, C. and H. Morin. 2005. Adventive-root development in mature black spruce and balsam fir in the boreal forests of Quebec, Canada. Can. J. For. Res. 35: 2642-2654.

Lindström, A. and G. Rune. 1999. Root deformation in plantations of container-grown Scots pine trees: effects on root growth, tree stability and stem straightness. Plant Soil 217: 29-37.

Lussier, J.M., H. Morin and R. Gagnon. 2002. Mortality in black spruce stands of fire or clear-cut origin. Can. J. For. Res. 32: 539-547. MacLean, D.A., A.W. Kline and D.R. Lavigne. 1984. Effectiveness of spruce budworm spraying in New Brunswick in protecting the spruce component of spruce-fir stands. Can. J. For. Res. 14: 163-176. Mailly, D. and M. Gaudreault. 2005. Models of internodal growth for the black spruce, the jack pine and the balsam fir in Quebec. For. Chron. 81: 114-124.

Milliken, G.A. and D.E. Johnson. 1992. Analysis of messy data. Vol. I: Designed experiments. Chapman and Hall, New York. 473 p.

[MRN] Ministère des Ressources naturelles. 2002. Rapport synthèse sur l'état des forêts québécoises 1995-1999. Gouvernement du Québec. $8 \mathrm{p}$.

2003. Zones de végétation et domaines bioclimatiques. Gouvernement du Québec. 2 p.

Monserud, R.A. 1988. Variations on a theme of site index. In A.R. Ek, S.R. Shifley and T.E. Burk (eds.). Forest growth modelling and prediction. pp. 419-427. USDA For. Serv. Gen. Tech. Rep. NC-120. Morin, H. and D. Laprise. 1990. Histoire récente de la Tordeuse des bourgeons de lépinette au nord du lac Saint-Jean (Québec) : une analyse dendrochronologique. Can. J. For. Res. 20: 1-8.

Motta, R. 1998. Dendroecology as a tool for evaluating past ungulate activity in forest stands. Two examples from the Italian Alps. In Proceedings of the international conference: Dendrochronology and environmental trends, 17-21 June, 1998, Kaunas, Lithuania. 
Nigh, G.D. 1997. Early height growth and site index of lodgepole pine under wet and dry soil moisture regimes in British Columbia. Wes. J. Appl. For. 12: 5-8.

Nigh, G.D. 1999. Years to breast height and green-up age models based on a juvenile height model for lodgepole pine. B.C. Min. For., Res. Br., Victoria, B.C. Ext. Note. 31.

Niklasson, M. 2002. A comparison of three age determination methods for suppressed Norway spruce: implications for age structure analysis. For. Ecol. Manage. 161: 279-288.

[OIFQ] Ordre des ingénieurs forestiers du Québec. 1996. Manuel de foresterie. Les Presses de l'Université Laval. 1428 p.

Parent, B. and C. Fortin. 2006. Ressources et industries forestières. Portrait statistique édition 2005-06. Gouvernement du Québec, Ministère des Ressources naturelles et de la Faune. 437 p.

Parent, S., H. Morin and C. Messier. 2000. Effects of adventitious roots on age determination in Balsam fir (Abies balsamea) regeneration. Can. J. For. Res. 30: 513-518.

Parent, S., H. Morin and C. Messier. 2002. Missing growth rings at the trunk base in suppressed balsam fir saplings. Can. J. For. Res. 32: 1776-1783.

Payette, S. and A. Delwaide. 2004. Dynamics of subarctic wetland forests over the past 1500 years. Ecol. Mono. 74: 373-391.

Philip, M.S. 1994. Measuring trees and forests. CABI Publishing 2nd edition. $336 \mathrm{p}$.

Piene, H. and C.H.A. Little. 1990. Spruce budworm defoliation and growth loss in young balsam fir: artificial defoliation of potted trees. Can. J. For. Res. 20: 902-909.

Piene, H. and D.A. MacLean. 1999. Spruce budworm defoliation and growth loss in young balsam fir: patterns of shoot, needle and foliage weight production over a nine-year outbreak cycle. For. Ecol. Manag. 123: 115-133.

Popovich, S. 1974. Volume par unité de surface terrière, comme moyen dévaluer la productivité de stations et la production des plantations dépinette blanche au Québec. Can. J. For. Res. 4: 127-137.

Prégent, G., V. Bertrand and L. Charette. 1996. Tables préliminaires de rendement pour les plantations dépinette noire au Québec. Québec Min. Ress. Nat. Mémoire de recherche forestière no. 118. Sainte-Foy, QC.

Prégent, G. and R. Poliquin. 2006. Bilan du second mesurage de la mesure des effets réels des plantations dépinettes blanche, noire, rouge et de Norvège, de mélèze laricin et de pin gris. Ministère des Ressources naturelles et de la Faune, Direction de la recherche forestière. Rapport interne $\mathrm{n}^{\circ} 491.54 \mathrm{p}$.

Prégent, G. and S. Végiard. 2000. Rendement anticipé des plantations d'épinette noire dans les domaines écologiques de la pessière noire. Direction de la recherche forestière, Forêt Québec. Note de recherche forestière no.109. Sainte-Foy, QC. 12 p.
Quinn, G.P. and M.J. Keough. 2002. Experimental design and data analysis for biologists. Cambridge University Press, Cambridge, United Kingdom. 537.

Raske, A.G. and W.J. Sutton. 1986. Decline and mortality of black spruce caused by spruce budworm defoliation and secondary organisms. Canadian Forestry Service, Newfoundland Forestry Centre, St. John's, NL. Information Report N-X-236.

Rowe, J.S. 1972. Les régions forestières du canada. Ministère de l'Environnement, Service canadien des forêts. Publ. no. 1300F, Ottawa. 172 p. Rozas, V. 2003. Regeneration patterns, dendroecology, and forestuse history in an old-growth beech-oak lowland forest in Northern Spain. For. Ecol. Manag. 182: 175-194.

Rubino, D.L. and B.C. McCarthy. 2004. Comparative analysis of dendroecological methods used to assess disturbance events. Dendrochronologia 21: 97-115.

Ruffner, C.M. and M.D. Abrams. 2003. Disturbance history and stand dynamics along a topographic gradient in old-growth hemlock-northern hardwood forests of the Allegheny Plateau, USA. Nat. Areas J. 23: 98-113.

SAS Institute Inc. 2003. JMP version 5.1 User's guide. Cary, NC.

Simard, M. and S. Payette. 2005. Reduction of black spruce seed bank by spruce budworm infestation compromises postfire stand regeneration. Can. J. For. Res. 35: 1686-1696.

Singh, T. 1987. Wood density variations in thirteen Canadian tree species. Wood Fib. Sci. 19: 362-369.

Telewski, F.W. 1993. Determining the germination date of woody plants: a proposed method for locating the root/shoot interface. Tree Ring Bulletin: 13-16.

Thiffault, N., R. Jobidon and A.D. Munson. 2003. Performance and physiology of large containerized and bare-root spruce seedlings in relation to scarification and competition in Quebec (Canada). Ann. For. Sci. 60: 645-655.

Viereck, L.A. and W. F. Johnston 1990. Picea mariana (Mill.) B.S.P.. In R.M. Burns and B.H. Honkala (eds.). Silvics of North America. USDA For. Serv., Agric. Handbook 654. Vol. 1. Conifers. Washington, DC.

Wang, G.G. 1998. Is height of dominant trees at a reference diameter an adequate measure of site quality? For. Ecol. Manag. 112: 49-54.

Wykoff, W.R. 1990. A basal area increment model for individual conifers in the northern Rocky Mountains. For. Sci. 36: 1077-1104.

Zhang, S.Y., D. Simpson and E.K. Morgenstern. 1996. Variation in the relationship of wood density with growth in 40 black spruce (Picea mariana) families grown in New Brunswick. Wood Fib. Sci. 28: 91-99. 